Cellular Physiology
and Biochemistry and Biochemistry Published online: May 31,2017

Accepted: March 28, 2017

This article is licensed under the Creative Commons Attribution-NonCommercial-NoDerivatives 4.0 International License (CC BY-NC-ND) (http://www.karger.com/Services/OpenAccessLicense). Usage and distribution for commercial purposes as well as any distribution of modified material requires written permission.

\title{
Roles of High Mobility Group Box 1 in Cardiovascular Calcification
}

\author{
Qiang Chen Ze-Yang Wang Li-Yuan Chen Hou-Yuan Hu
}

Department of Cardiology, Southwest Hospital, Third Military Medical University, Chongqing, China

\section{Key Words}

High mobility group box 1 - Cardiovascular calcification - Calcific extracellular vesicles • Osteochondrogenic differentiation

\begin{abstract}
Calcific disease of the cardiovascular system, including atherosclerotic calcification, medial calcification in diabetes and calcific aortic valve disease, is an important risk factor for many adverse cardiovascular events such as ischemic cardiac events and subsequent mortality. Although cardiovascular calcification has long been considered to be a passive degenerative occurrence, it is now recognized as an active and highly regulated process that involves osteochondrogenic differentiation, apoptosis and extracellular vesicle release. Nonetheless, despite numerous studies on the pathogenesis of cardiovascular calcification, the underlying mechanisms remain poorly understood. High mobility group box 1 (HMGB1), a nuclear protein bound to chromatin in almost all eukaryotic cells, acts as a damage-associated molecular pattern (DAMP) when released into the extracellular space upon cell activation, injury or death. Moreover, HMGB1 also functions as a bone-active cytokine participating in bone remodeling and ectopic calcification pathogenesis. However, studies on the roles of HMGB1 in promoting cardiovascular calcification are limited to date, and the mechanisms involved are still unclear. In this review, we summarize recent studies investigating the mechanism of cardiovascular calcification and discuss multiple roles of HMGB1 in its development.

\section{Introduction}

The entire cardiovascular system is vulnerable to pathological calcification [1], and vascular disease, such as atherosclerosis, arteriosclerosis and diabetic vasculopathy, is frequently complicated by calcification [2]. Calcification in arteries can be widespread, and the prevalence increases with age. Indeed, more than $60 \%$ of adults over the age 60 
years have calcium deposits in at least one of the major vascular beds, such as the carotid arteries, coronary arteries and intrathoracic aorta [3]. Cardiovascular calcification leads to a multitude of clinical manifestations. Intimal calcification, which is always associated with atherosclerotic plaque, can lead to myocardial infarction or ischemia in both coronary and peripheral arteries. In larger arteries such as the aorta, medial calcification can lead to increased pulse wave velocity and systolic hypertension, a known risk factor for cardiovascular disease in the general population. Another common site of calcification is the aortic valve, termed calcific aortic valvular disease (CAVD), which has severe consequences. Approximately $40 \%$ of people over the age of 70 years have mild calcification of the aortic valve, with over $10 \%$ having severe calcification [1]. Lastly, calcification of arterioles of the skin and other organs can lead to localized infarction and ischemia, including ischemic bowel and calciphylaxis [4].

Previously believed to be an end-stage process of unregulated mineral precipitation, cardiovascular calcification is now well established as a multi-faceted disease influenced by vascular location, the origin of calcifying cells and numerous regulatory pathways [2]. The pathogenesis of cardiovascular calcification is complex and involves transformation of vascular smooth muscle cells (VSMCs) to osteo/chondrocytic cells that express Runt-related transcription factor 2 (Runx2) and produce matrix vesicles. Imbalance of calcification promoters (such as BMP2, advanced glycation end-products (AGEs), hyperphosphatemia and hypercalcemia) and inhibitors (such as fetuin-A, matrix Gla protein and pyrophosphate) is critical for the development of cardiovascular calcification [4]. Furthermore, inflammation likely plays a significant role in its development. For example, results from in vitro studies and animal models of atherosclerosis suggest that inflammatory cytokines such as tumor necrosis factor (TNF) and interleukin-6 (IL-6) promote osteochondrogenic differentiation and vascular intimal calcification [5-7]. Inflammatory cytokines induce generation of reactive oxygen species (ROS), which have also been implicated in cardiovascular calcification [8]. Moreover, the $\mathrm{pH}$ of acidic cellular compartments also plays a role in osteo-/chondrogenic transformation and calcification of VSMCs [9].

High mobility group box 1 (HMGB1) is a nuclear constituent bound to chromatin in nearly all eukaryotic cells [10]. When released into the extracellular space upon cell activation, injury or death, HMGB1 functions as a damage-associated molecular pattern (DAMP) [11], and extracellular HMGB1 has drawn increasing attention with regard to its involvement in the pathogenesis of autoimmune and inflammatory diseases [12-14]. HMGB1 is also known as a bone-active cytokine that participates in both bone remodeling and ectopic calcification pathogenesis $[15,16]$. Moreover, there is evidence that HMGB1 accumulates extracellularly in areas associated with macrophage infiltration and calcification in calcific aortic valve stenosis [17]. Wang et al. reported increased tissue and plasma levels of HMGB1 in patients with calcific aortic valve disease [18]. Our recent study demonstrated that HMGB1 induces matrix vesicle secretion by macrophages and leads to subsequent ectopic mineralization both in vitro and in vivo [19]. In addition, HMGB1 directly mediates VSMC osteoblastic differentiation in patients with diabetes [20].

However, studies about the roles of HMGB1 in promoting cardiovascular calcification are limited, and the underlying mechanisms remain unclear. In this review, we summarize recent studies on the mechanism of cardiovascular calcification and discuss the multiple roles of HMGB1 in the development of this condition.

\section{The Basic Actions of HMGB1}

In 1973, Goodwin discovered a group of nonhistone nuclear proteins characterized by high electrophoretic mobility and termed them high mobility group (HMG) proteins. These proteins include three superfamilies: HMGB, HMGN, and HMGA [21,22]. HMGB1, also known as amphoterin, is a $30-\mathrm{kDa}$ non-histone, chromatin-binding protein ubiquitously expressed in eukaryotic cells $[23,24]$. The protein is 215 amino acids long and has a tripartite structure 
consisting of two DNA-binding domains, an A box and a B box, and a C-terminal tail domain [25]. Constitutively expressed in most cell types, HMGB1 is predominantly located in the nucleus under physiological conditions, where it acts as a structural component in complex with chromatin and certain co-transcription factors. HMGB1 facilitates assembly of nuclear proteins and participates in DNA replication, recombination, transcription and repair [26, 27]. However, upon cell activation, injury or death, HMGB1 is translocated outside of the cell $[9,28]$. Recent evidence reveals that the initial translocation of HMGB1 from the nuclear to the cytoplasm is regulated by JAK/STAT1-mediated acetylation [29], with subsequent extracellular release being partly controlled by dsRNA-activated protein kinase R (PKR)/ inflammasome-mediated pyroptosis [30].

By binding to various receptors on the surface of immune competent cells, extracellular HMGB1 becomes a proinflammatory mediator serving as a DAMP or a so-called alarmin to stimulate the innate immune system [31-34]. In the extracellular environment, HMGB1 regulates inflammation as well as cell proliferation, survival and migration upon interaction with high-affinity receptors including receptor of advanced glycation end-products (RAGE), Toll-like receptors (TLRs) 2, -4, and -9, CXCR4, macrophage antigen-1, syndecan-3, CD24Siglec-10, and T cell Igmucin-3 $[9,21,34]$. The role of HMGB1 has been investigated in several systemic disorders, including sepsis, cancer, kidney diseases [36], thrombosis [37, 38], and certain autoimmune diseases such as systemic lupus erythematosus (SLE) and rheumatoid arthritis (RA) [9, 33, 34]. HMGB1 is also a critical mediator in vascular diseases [39] such as atherosclerosis [35, 40,41], myocardial ischemia/reperfusion (I/R) injury [42, 43], heart failure $[44,45]$, acute coronary syndrome (ACS) [46, 47], vasculitis [34], pulmonary artery disease [48-50], cerebral artery disease [51-53], and peripheral artery diseases (PADs) [54, 55].

\section{Possible Mechanisms by Which HMGB1 Promotes Cardiovascular Calcification}

Cardiovascular calcification is an age-related disease, particularly in association with atherosclerosis and diabetes mellitus [56]. It is currently acknowledged that aging is associated with a low-grade chronic inflammatory status, which can contribute to HMGB1 release [57]. Indeed, in atherosclerotic plaque and calcific aortic valve disease, HMGB1 is always found co-localized with calcification nidus [17]. Here, we review the literature on extracellular HMGB1 and its role in cardiovascular calcification. In addition, we present a schematic incorporating both the documented and speculated roles of HMGB1 in the pathogenesis of cardiovascular calcification.

\section{HMGB1 and osteochondrogenic phenotype change}

Several sources of cells that undergo osteochondrogenic differentiation in the vascular wall have been identified, including VSMCs, pericytes, adventitial myofibroblasts, interstitial valve cells, and circulating or stationary progenitor cells [2]. Aortic and valvular endothelial cells also have been shown to transition to cells that undergo osteochondrogenesis via the endothelial to mesenchymal transition (EMT) $[58,59]$. Cells exhibiting an osteochondrogenic phenotype have the potential to generate mineralized matrix, resulting in calcified deposits [60]. Some studies have reported that HMGB1 participates in osteochondrogenic differentiation of certain cell types. Qi and his colleagues revealed that during human dental pulp cell (hDPC) odontoblastic differentiation, HMGB1 is translocated from the nucleus to the cytoplasm and then secreted into the extracellular space, promoting hDPC proliferation and mineralized nodule formation [61]. Similar results were observed in human periodontal ligament cells, which have been shown to undergo proliferation, migration, osteogenic differentiation, and biomineralization when exposed to HMGB1 [61]. Recently, it was demonstrated that HMGB1 can trigger the differentiation of mesenchymal stem cells into osteoblasts, which may provide a theoretical basis for improving clinical treatments for fractures $[63,64]$. Wang et al. observed that HMGB1 promotes osteoblastic differentiation 


\section{Cellular Physiology Cell Physiol Biochem 2017;42:427-440

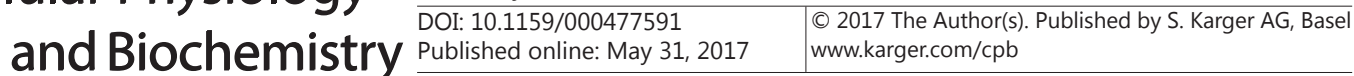 \\ Chen et al.: Roles of HMGB1 in Cardiovascular Calcification}

and calcification of aortic valve interstitial cells (VICs) through TLR4-JNK-NF- $\kappa B$ signaling [65].

Runx2, a key transcription factor of the Runx family, regulates osteoblast differentiation and chondrocyte maturation [66] and is an essential and sufficient regulator for inducing osteochondrogenic differentiation and calcification [66-68]. In normal vascular cells, expression of Runx2 is very low. However, Runx2 expression is significantly increased in calcified vascular tissue specimens from atherosclerotic plaque and arteries of chronic kidney disease (CKD) patients [68-71], suggesting an important role in cardiovascular calcification pathogenesis [72]. Runx2 influences cardiovascular calcification by regulating several osteogenic marker genes such as ALP, type I collagen, bone sialoprotein, and osteopontin [73]. HMGB1 can up-regulated the expression of RUNX2 and its downstream osteogenic markers such as alkaline phosphatase (ALP), osteopontin, and osteocalcin [62, 64]. These findings support the hypothesis that HMGB1 promotes cardiovascular calcification by inducing osteochondrogenic differentiation in multiple cells.

\section{HMGB1 and TGF- $\beta / B M P$ signaling}

The transforming growth factor- $\beta$ (TGF- $\beta$ ) superfamily of proteins contains cytokines and peptide growth factors that regulate biological functions in many systems, including heart valves and blood vessels [74]. TGF- $\beta$ and its signaling pathways are strongly associated with fibrosis [75] and calcification [76], and previous studies show that TGF- $\beta$ is characteristically present within calcified stenotic aortic cusps and mediates the calcification process of aortic valve interstitial cells in culture $[77,78]$. Within the context of atherosclerotic calcification progression, TGF- $\beta$ is abundantly expressed in VSMCs and promotes their osteogenic differentiation and calcifying potential [79]. A recent study by Krohn et al. showed that TGF- $\beta$ induces the release of calcifying extracellular vesicles from VSMCs via the Smad3 and p38 pathways and regulates the vascular fibrocalcific response in atherosclerotic plaque [80]. Bone morphogenetic proteins (BMPs), which constitute a sub-group of the TGF- $\beta$ superfamily, are potent activators of osteogenic differentiation and among the earliest factors described in the calcified artery wall [2].

Several interactions have been reported between HMGB1 and TGF- $\beta$ or BMPs. For instance, Cheng et al. found that HMGB1 enhances AGE-induced expression of TGF- $\beta$ in renal tubular epithelial cells via RAGE-dependent signaling [81]. HMGB1 was also recently shown to act through RAGE/NF- $\kappa \mathrm{B} /$ heparanase signaling to enhance active TGF- $\beta$ release from the myofibroblast extracellular matrix (ECM) [82]. In addition, HMGB1 has an important role in mediating the calcification process induced by high glucose through BMP-2 expression in VSMCs of the saphenous vein [83]. These studies suggest that HMGB1 regulates the expression or release of TGF- $\beta$ and BMP2 and may thus further promote cardiovascular calcification [84].

\section{HMGB1 in secretion of calcific extracellular vesicles}

Extracellular vesicles (e.g., microparticles, exosomes, matrix vesicles, apoptotic bodies) are membrane micro/nanovesicles secreted under physiological and pathological conditions by many cell types into the circulation and the extracellular milieu. Emerging evidence suggests that calcification may be initiated by the release of calcifying extracellular vesicles from cells residing in the calcification niche [80]. Matrix vesicles were initially found to be secreted from hypertrophic chondrocytes and osteoblasts during osteogenesis [85], initiating mineralization in two phases. First, in matrix vesicles, influx of calcium and phosphate via annexins and sodium-dependent inorganic phosphate transporters, respectively, leads to initial mineral accumulation in the form of hydroxyapatite crystals near the membrane. Second, mineral propagation in the ECM occurs, whereby hydroxyapatite crystals grow within the vesicles until the membrane ruptures; once exposed to the ECM, the crystals act as loci or templates for the formation of new crystals via homologous nucleation [85-88]. Alexander et al. observed that matrix vesicles released by VSMCs are also exosomallike vesicles and that increased exosome release promotes cardiovascular calcification in 
response to environmental calcium stress [89]. In addition, VSMC apoptosis often occurs in a several pathologic conditions and as a normal consequence of aging and stress. Apoptotic bodies derived from VSMCs have been shown to act as a nucleating structure for calcium crystal formation [90].

In our recent study, we demonstrated that HMGB1 can induce secretion of matrix vesicles by macrophages via the RAGE/p38/nSMase2 signaling pathway, and leads to subsequent mineralization in vitro and in vivo [19]. Moreover, HMGB1 was found to control the cellular apoptosis checkpoint during inflammation [91], hypoxia/reoxygenation injury [92] and hyperglycemia-induced apoptosis [93], which may be accompanied by release of a number of apoptotic bodies. All these findings support the hypothesis that HMGB1 promotes cardiovascular calcification by regulating the release of calcific extracellular vesicles.

\section{HMGB1 in inflammation}

Inflammation is likely to play a significant role in the development of cardiovascular calcification associated with atherosclerosis and diabetes mellitus, which has been confirmed in molecular imaging studies. Indeed, Abdelbaky et al. showed focal aortic inflammation, as detected by $18 \mathrm{~F}$-deoxyglucose positron emission tomographic scanning, in the aortic valve and atherosclerotic plaque to be significantly higher among patients who exhibited subsequent calcification progression [94]. Although cardiovascular calcification in the medial layer in association with CKD appears to link to long-term elevation of serum phosphate levels, apoptosis and uremic derangements [56], inflammation also acts in this process [95]. By releasing extracellular vesicles containing a phosphatidylserine-annexinV-S100A9 complex that facilitates mineral nucleation, macrophages are involved in the early, proinflammatory phase of calcification in atherosclerotic plaques [96]. Inflammatory cytokines, including TNF- $\alpha$, IL-1 and IL-6, are associated with increased cardiovascular calcification $[97,98]$, and in a cohort free of clinically apparent cardiovascular disease, high C-reactive protein levels were associated with coronary artery calcification in both men and women [99]. Inflammatory cytokines such as TNF- $\alpha$ and IL-1 may exert their effects by stimulating the release of BMP-2 [100-102] or may enhance BMP-2 activity by reducing the levels of its inhibitor, matrix Gla protein (MGP) [97]. TNF- $\alpha$ also enhances matrix vesicle secretion by VSMCs [89].

HMGB1 is one of the endogenous mediators activating processes that lead to inflammation in the arterial wall. HMGB1 was also found to be associated with macrophage infiltration and areas of collagen accumulation and calcification [103]. Recombinant HMGB1 activates vascular endothelial cells, leading to expression of intercellular adhesion molecule 1 (ICAM-1), vascular cell adhesion molecule 1 (VCAM-1), E-selectin and monocyte chemotatic protein 1 (MCP-1), all of which contribute to leukocyte adherence and infiltration $[104,105]$. Furthermore, HMGB1 promotes VSMC proliferation and osteochondrogenic differentiation and migration to the intimal layer in the development of atherosclerosis [41, 106], and growing evidence supports the role of inflammation in ECM remodeling, which drives the pathophysiology of cardiovascular calcification [1]. Moreover, HMGB1 is required for collagen deposition [106], ECM synthesis [108] and vessel remodeling [109, 110]. These observations suggest that HMGB1-induced inflammation participates in the initiation and propagation of cardiovascular calcification, particularly atherosclerotic calcification.

\section{HMGB1 and Oxidative stress}

In general, oxidative stress represents an imbalance between increased production of ROS and a reduction in the expression and activity of cellular antioxidant defense mechanisms. In the vascular wall, ROS are produced by several enzymes, including NADPH oxidase, xanthine oxidase, and uncoupled endothelial nitric oxide synthase (eNOS), as well as the mitochondrial electron transport chain. Nonetheless, the vasculature is protected by antioxidant enzymes, including superoxide dismutase (SOD), catalase, glutathione peroxidase and paraoxonase, which detoxify ROS. Cardiovascular risk factors such as hypercholesterolemia, hypertension, and diabetes mellitus enhance ROS generation, resulting in oxidative stress [111].

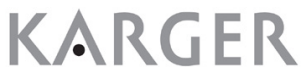


Fig. 1. Proposed roles of HMGB1 in cardiovascular calcification. HMGB1, high mobility group box 1; RAGE, receptor for advanced glycation end products; nSMase2, neutral sphingomyelinase2; TGF- $\beta$, transforming growth factor- $\beta$; BMP, bone morphogenetic protein; ROS, reactive oxygen species; EVs, extracellular vesicles; VSMCs, vascular smooth muscle cells; IVC, interstitial valve cell; Runx2, runt-related transcription factor 2; MSX2, Msh homeobox 2; ALP, alkaline phosphatase; OPN, osteopontin; OCN, osteocalcin; BSP, bone sialoprotein.

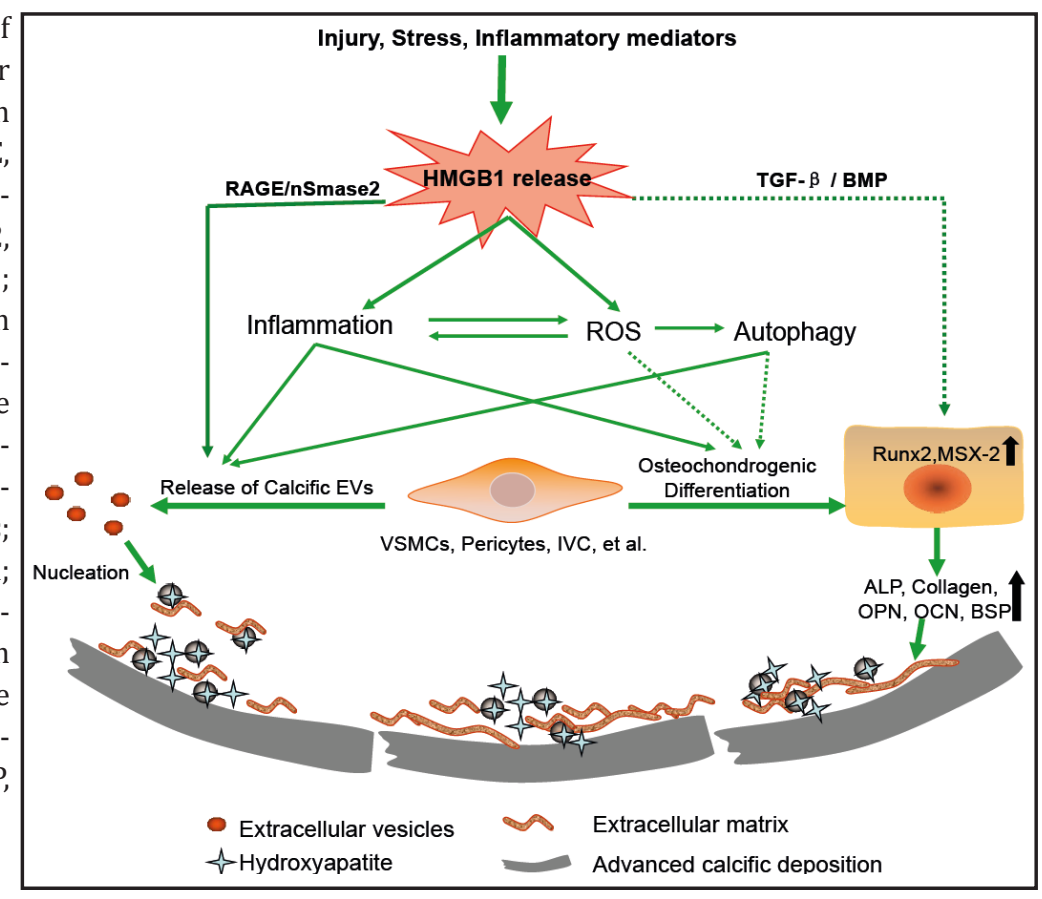

Increased levels of ROS and oxidative stress have been shown to participate in the pathogenesis of cardiovascular calcification [112]. Heightened ROS generation has been predominately found around calcifying foci, potentiating aortic valve calcification progression in rabbits [113]. Furthermore, ROS, especially superoxide produced by NADPH oxidase, mediate osteoblastic differentiation, ECM disorganization and cardiovascular calcification induced by uremic serum [114] or $\beta$-glycerophosphate [115], BMP-2 [116], AGEs $[117,118]$ and the proinflammatory cytokine TNF- $\alpha[119,120]$. In addition, much evidence suggests that antioxidants might have potential benefits in the management of cardiovascular calcification. For example, vitamin $\mathrm{E}$ was found to antagonize acceleration of cardiovascular calcification in hypercholesterolemia-induced rats [121], and the antioxidant TEMPOL, a SOD mimetic, ameliorated osteoblastic differentiation of VSMCs and arterial medial calcification in uremic rats [122]. Together, these data confirm that oxidative stress plays a critical role in the pathogenesis of cardiovascular calcification.

Previous studies have indicated that oxidative stress can regulate HMGB1 release in various cells [123] and mediate differentiation induced by ROS [124]. HMGB1 has also been shown to enhance ROS via a positive feedback loop in the apoptotic process of diabetic retinopathy [125] and diabetes-induced endothelial progenitor cell dysfunction [126]. Through TLR4-ROS signaling, HMGB1 impairs cardiac excitation-contraction coupling by enhancing sarcoplasmic reticulum $\mathrm{Ca}^{2+}$ leakage in cardiomyocytes [127]. Taken together, mutual enhancement between HMGB1 and oxidative stress may further promote cardiovascular calcification, and the mechanisms underlying this process are possibly involved in osteochondrogenic differentiation and apoptosis.

\section{HMGB1 and Autophagy}

Homeostasis and rapid adaptation to environmental changes are vital to organismal health and survival. Autophagy is an evolutionarily conserved process by which long-lived proteins and organelles are sequestered by autophagosomes and subsequently degraded by lysosomes for recycling [128]. Growing evidence reveals that basal autophagy is essential to the process that mediates proper vascular function. Moreover, autophagy is induced by many stress-related stimuli in the vascular wall to protect VSMCs and endothelial cells against cell death and the initiation of vascular diseases such as atherosclerosis, aneurysm formation, arterial aging, vascular stiffness, and chronic venous disease $[129,130]$. It 


\section{Cellular Physiology Cell Physiol Biochem 2017;42:427-440 \begin{tabular}{l|l} 
and Biochemistry $10.1159 / 000477591$ \\
Published online: May 31, 2017
\end{tabular}$\quad \begin{aligned} & \text { O } 2017 \text { The Author(s). Published by S. Karger AG, Basel } \\
& \text { www.karger.com/cpb }\end{aligned}$ \\ Chen et al.: Roles of HMGB1 in Cardiovascular Calcification}

appears that autophagy affects cardiovascular calcification. However, most of the work thus far has focused on the role of autophagy in osteoblastic differentiation. One study reported that autophagy is involved in the osteogenic differentiation of odontoblasts [131] and human osteoblast associated with the titanium-based dental implants [132]. In mesenchymal stem cells (MSCs), autophagy is induced by forkhead box 03 (FOXO3) to reduce ROS resulting from the increased mitochondrial respiration that occurs during osteoblast differentiation [133] and may regulate osteogenic differentiation via AMPK/Akt/mTOR signaling [134]. VSMCs stimulated with platelet-derived growth factor (PDGF) show autophagy induction, which regulates a synthetic phenotypic transition in response to oxidative stress [135]. Furthermore, Dai et al. recently described that VSMCs treated with high phosphate exhibit upregulation of autophagic markers such as LC3 and autophagosomes in the cytoplasm, which can counteract cardiovascular calcification by reducing matrix vesicle release [136]. In addition, TGF- $\beta 1$-stimulated calcification of VSMCs can be alleviated by atorvastatininduced autophagy [137], which also indicates the important role of autophagy in regulating cardiovascular calcification.

Accumulating data suggest that HMGB1 is an important autophagy regulator during cell stress. A recent study from Zhu et al. reports that cytosolic HMGB1 controls the cellular autophagy/apoptosis checkpoint during inflammation [91]. In addition, HMGB1-mediated autophagy regulates the differentiation of acute promyelocytic leukemia cells in response to oxidative stress [124]. Given the role of autophagy in cardiovascular calcification, it appears reasonable that HMGB1 may strongly influence cardiovascular calcification by regulating autophagy.

\section{Conclusions}

The possible mechanisms of HMGB1 in cardiovascular calcification are depicted in Fig. 1. Although evidence suggesting the direct involvement of HMGB1 in cardiovascular calcification is limited, an increasing number of studies have shown that both extracellular and cytosolic HMGB1 have a series of pro-calcification effects, such as promoting osteochondrogenic differentiation, apoptosis and release of calcific extracellular vesicles via TGF- $\beta /$ BMP, inflammation, oxidative stress and autophagy signaling. These results highlight the fact that inhibition of HMGB1 may be a potential therapy for attenuating cardiovascular calcification. Regardless, the mechanisms by which HMGB1 promotes cardiovascular calcification have not been fully elucidated. Thus, future studies should pay particular attention to exploring these mechanisms in detail. Recently, some approaches have been shown to be protective in models of vascular pathologies at least in part, via inhibiting HMGB1 expression, release, or activity [39, 138-140]. With more clues uncovered, other approaches to preventing HMGB1 release or binding to its receptors will provide novel strategies for treating cardiovascular calcification and reducing cardiovascular events. However, as HMGB1 also functions as a bone-active cytokine [15], future studies also should notice the impact of inhibiting HMGB1 on skeletal calcification.

\section{Acknowledgements}

This work was supported by the grants from the National Natural Science Foundation of China (No. 81470561 and No. 81270362).

\section{Disclosure Statement}

The authors declare no conflict of interest. 


\section{Cellular Physiology Cell Physiol Biochem 2017;42:427-440

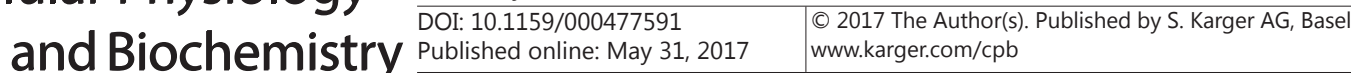

Chen et al.: Roles of HMGB1 in Cardiovascular Calcification

\section{References}

1 Hsu JJ, Lim J, Tintut Y, Demer LL: Cell-matrix mechanics and pattern formation in inflammatory cardiovascular calcification. Heart 2016;102:1710-1715.

- Bostrom KI: Where do we stand on vascular calcification? Vascul Pharmacol 2016;84:8-14.

- Allison MA, Criqui MH, Wright CM: Patterns and risk factors for systemic calcified atherosclerosis. Arterioscler Thromb Vasc Biol 2004;24:331-336.

-4 Chen NX, Moe SM: Pathophysiology of Vascular Calcification. Curr Osteoporos Rep 2015;13:372-380.

-5 Tintut Y, Patel J, Parhami F, Demer LL: Tumor necrosis factor-alpha promotes in vitro calcification of vascular cells via the cAMP pathway. Circulation 2000;102:2636-2642.

-6 Shioi A, Katagi M, Okuno Y, Mori K, Jono S, Koyama H, Nishizawa Y: Induction of bone-type alkaline phosphatase in human vascular smooth muscle cells: roles of tumor necrosis factor-alpha and oncostatin $\mathrm{M}$ derived from macrophages. Circ Res 2002;91:9-16.

7 Al-Aly Z, Shao JS, Lai CF, Huang E, Cai J, Behrmann A, Cheng SL, Towler DA: Aortic Msx2-Wnt calcification cascade is regulated by TNF-alpha-Dependent signals in diabetic Ldlr(-/-) mice. Arterioscler Thromb Vasc Biol 2007;27:2589-2596.

8 Agharazii M, St-Louis R, Gautier-Bastien A, Ung RV, Mokas S, Lariviere R, Richard DE: Inflammatory Cytokines and Reactive Oxygen Species as Mediators of Chronic Kidney Disease-Related Vascular Calcification. Am J Hypertens 2015;28:746-755.

-9 Alesutan I, Musculus K, Castor T, Alzoubi K, Voelkl J, Lang F: Inhibition of Phosphate-Induced Vascular Smooth Muscle Cell Osteo-/Chondrogenic Signaling and Calcification by Bafilomycin A1 and Methylamine. Kidney Blood Press Res 2015;40:490-499.

10 Harris HE, Andersson U, Pisetsky DS: HMGB1: a multifunctional alarmin driving autoimmune and inflammatory disease. Nat Rev Rheumatol 2012;8:195-202.

11 Scaffidi P, Misteli T, Bianchi ME: Release of chromatin protein HMGB1 by necrotic cells triggers inflammation. Nature 2002;418:191-195.

12 Jia L, Clear A, Liu FT, Matthews J, Uddin N, McCarthy A, Hoxha E, Durance C, Iqbal S, Gribben JG: Extracellular HMGB1 promotes differentiation of nurse-like cells in chronic lymphocytic leukemia. Blood 2014;123:1709-1719.

13 Kang R, Zhang QH, Zeh HJ, Lotze MT, Tang DL: HMGB1 in Cancer: Good, Bad, or Both? Clin Cancer Res 2013;19:4046-4057.

14 Cai JJ, Wen J, Bauer E, Zhong H, Yuan H, Chen AF: The Role of HMGB1 in Cardiovascular Biology: Danger Signals. Antioxid Redox Signal 2015;23:1351-1369.

15 Yang JP, Shah R, Robling AG, Templeton E, Yang H, Tracey KJ, Bidwell JP: HMGB1 is a bone-active cytokine.J Cell Physiol 2008;214:730-739.

-16 Zhou Z, Han JY, Xi CX, Xie JX, Feng X, Wang CY, Mei L, Xiong WC: HMGB1 regulates RANKL-induced osteoclastogenesis in a manner dependent on RAGE. J Bone Miner Res 2008;23:1084-1096.

17 Passmore M, Nataatmadja M, Fung YL, Pearse B, Gabriel S, Tesar P, Fraser JF: Osteopontin alters endothelial and valvular interstitial cell behaviour in calcific aortic valve stenosis through HMGB1 regulation. Eur J Cardiothorac Surg 2015;48:E20-E29.

- 18 Wang B, Wei G, Liu B, Zhou X, Xiao H, Dong N, Li F: The Role of High Mobility Group Box 1 Protein in Interleukin-18-Induced Myofibroblastic Transition of Valvular Interstitial Cells. Cardiology 2016;135:168178.

19 Chen Q, Bei JJ, Liu C, Feng SB, Zhao WB, Zhou Z, Yu ZP, Du XJ, Hu HY: HMGB1 Induces Secretion of Matrix Vesicles by Macrophages to Enhance Ectopic Mineralization. PLoS One 2016;11:e0156686.

20 Wang YY, Shan JG, Yang WG, Zheng H, Xue S: High Mobility Group Box 1 (HMGB1) Mediates High-GlucoseInduced Calcification in Vascular Smooth Muscle Cells of Saphenous Veins. Inflammation 2013;36:15921604.

21 Goodwin GH, Sanders C, Johns EW: A new group of chromatin-associated proteins with a high content of acidic and basic amino acids. Eur J Biochem 1973;38:14-19.

22 Wan W, Cao L, Khanabdali R, Kalionis B, Tai X, Xia S: The Emerging Role of HMGB1 in Neuropathic Pain: A Potential Therapeutic Target for Neuroinflammation. J Immunol Res 2016;2016:6430423.

23 Muller S, Ronfani L, Bianchi ME: Regulated expression and subcellular localization of HMGB1, a chromatin protein with a cytokine function.J Intern Med 2004;255:332-343. 


\section{Cellular Physiology Cell Physiol Biochem 2017;42:427-440 \begin{tabular}{l|l} 
DOI: 10.1159/000477591 & $\begin{array}{l}\text { O 2017 The Author(s). Published by S. Karger AG, Basel } \\
\text { www.karger.com/cpb }\end{array}$
\end{tabular}}

Chen et al.: Roles of HMGB1 in Cardiovascular Calcification

24 Bianchi ME, Falciola L, Ferrari S, Lilley DM: The DNA binding site of HMG1 protein is composed of two similar segments (HMG boxes), both of which have counterparts in other eukaryotic regulatory proteins. EMBO J 1992;11:1055-1063.

25 Wen L, Huang JK, Johnson BH, Reeck GR: A human placental cDNA clone that encodes nonhistone chromosomal protein HMG-1. Nucleic Acids Res 1989;17:1197-1214.

26 Einck L, Bustin M: The intracellular distribution and function of the high mobility group chromosomal proteins. Exp Cell Res 1985;156:295-310.

27 Malarkey CS, Churchill MEA: The high mobility group box: the ultimate utility player of a cell. Trends Biochem Sci 2012;37:553-562.

-28 Yanai H, Ban T, Taniguchi T: High-mobility group box family of proteins: ligand and sensor for innate immunity. Trends Immunol 2012;33:633-640.

29 Lu B, Antoine DJ, Kwan K, Lundback P, Wahamaa H, Schierbeck H, Robinson M, Van Zoelen MA, Yang H, Li J, Erlandsson-Harris H, Chavan SS, Wang H, Andersson U, Tracey KJ: JAK/STAT1 signaling promotes HMGB1 hyperacetylation and nuclear translocation. Proc Natl Acad Sci U S A 2014;111:3068-3073.

-30 Lu B, Nakamura T, Inouye K, Li JH, Tang YT, Lundback P, Valdes-Ferrer SI, Olofsson PS, Kalb T, Roth J, Zou YR, Erlandsson-Harris H, Yang H, Ting JPY, Wang HC, Andersson U, Antoine DJ, Chavan SS, Hotamisligil GS, Tracey KJ: Novel role of PKR in inflammasome activation and HMGB1 release. Nature 2012;488:670

- 31 Andersson U, Tracey KJ: HMGB1 Is a Therapeutic Target for Sterile Inflammation and Infection. Annu Rev Immunol, Vol 29 2011;29:139-162.

-32 Chen Y, Sun W, Gao RF, Su YY, Umehara H, Dong LL, Gong FL: The role of high mobility group box chromosomal protein 1 in rheumatoid arthritis. Rheumatology 2013;52:1739-1747.

-33 Yang H, Antoine DJ, Andersson U, Tracey KJ: The many faces of HMGB1: molecular structure-functional activity in inflammation, apoptosis, and chemotaxis. J Leukoc Biol 2013;93:865-873.

-34 Wang C, de Souza AW, Westra J, Bijl M, Chen M, Zhao MH, Kallenberg CG: Emerging role of high mobility group box 1 in ANCA-associated vasculitis. Autoimmun Rev 2015;14:1057-1065.

-35 de Souza AW, Westra J, Limburg PC, Bijl M, Kallenberg CG: HMGB1 in vascular diseases: Its role in vascular inflammation and atherosclerosis. Autoimmun Rev 2012;11:909-917.

-36 Chen Q, Guan X, Zuo X, Wang J, Yin W: The role of high mobility group box 1 (HMGB1) in the pathogenesis of kidney diseases. Acta Pharm Sin B 2016;6:183-188.

-37 Stark K, Philippi V, Stockhausen S, Busse J, Antonelli A, Miller M, Schubert I, Hoseinpour P, Chandraratne S, von Bruhl ML, Gaertner F, Lorenz M, Agresti A, Coletti R, Antoine DJ, Heermann R, Jung K, Reese S, Laitinen I, Schwaiger M, Walch A, Sperandio M, Nawroth PP, Reinhardt C, Jackel S, Bianchi ME, Massberg S: Disulfide HMGB1 derived from platelets coordinates venous thrombosis in mice. Blood 2016;128:2435-2449.

-38 Vogel S, Bodenstein R, Chen Q, Feil S, Feil R, Rheinlaender J, Schaffer TE, Bohn E, Frick JS, Borst O, Munzer P, Walker B, Markel J, Csanyi G, Pagano PJ, Loughran P, Jessup ME, Watkins SC, Bullock GC, Sperry JL, Zuckerbraun BS, Billiar TR, Lotze MT, Gawaz M, Neal MD: Platelet-derived HMGB1 is a critical mediator of thrombosis. J Clin Invest 2015;125:4638-4654.

-39 Cai J, Wen J, Bauer E, Zhong H, Yuan H, Chen AF: The Role of HMGB1 in Cardiovascular Biology: Danger Signals. Antioxid Redox Signal 2015;23:1351-1369.

- 40 Kanellakis P, Agrotis A, Kyaw TS, Koulis C, Ahrens I, Mori S, Takahashi HK, Liu K, Peter K, Nishibori M, Bobik A: High-mobility group box protein 1 neutralization reduces development of diet-induced atherosclerosis in apolipoprotein e-deficient mice. Arterioscler Thromb Vasc Biol 2011;31:313-319.

-41 Inoue K, Kawahara K, Biswas KK, Ando K, Mitsudo K, Nobuyoshi M, Maruyama I: HMGB1 expression by activated vascular smooth muscle cells in advanced human atherosclerosis plaques. Cardiovasc Pathol 2007;16:136-143.

42 Andrassy M, Volz HC, Igwe JC, Funke B, Eichberger SN, Kaya Z, Buss S, Autschbach F, Pleger ST, Lukic IK, Bea F, Hardt SE, Humpert PM, Bianchi ME, Mairbaurl H, Nawroth PP, Remppis A, Katus HA, Bierhaus A: Highmobility group box-1 in ischemia-reperfusion injury of the heart. Circulation 2008;117:3216-3226.

43 Oozawa S, Mori S, Kanke T, Takahashi H, Liu K, Tomono Y, Asanuma M, Miyazaki I, Nishibori M, Sano S: Effects of HMGB1 on ischemia-reperfusion injury in the rat heart. Circ J 2008;72:1178-1184.

44 Volz HC, Kaya Z, Katus HA, Andrassy M: The Role of HMGB1/RAGE in Inflammatory Cardiomyopathy. Semin Thromb Hemost 2010;36:185-194. 


\section{Cellular Physiology Cell Physiol Biochem 2017;42:427-440 \begin{tabular}{l|l} 
DOI: 10.1159/000477591 & O 2017 The Author(s). Published by S. Karger AG, Basel \\
www.karger.com/cpb
\end{tabular}}

Chen et al.: Roles of HMGB1 in Cardiovascular Calcification

45 Volz HC, Seidel C, Laohachewin D, Kaya Z, Muller OJ, Pleger ST, Lasitschka F, Bianchi ME, Remppis A, Bierhaus A, Katus HA, Andrassy M: HMGB1: the missing link between diabetes mellitus and heart failure. Basic Res Cardiol 2010;105:805-820.

46 Kohno T, Anzai T, Naito K, Miyasho T, Okamoto M, Yokota H, Yamada S, Maekawa Y, Takahashi T, Yoshikawa T, Ishizaka A, Ogawa S: Role of high-mobility group box 1 protein in post-infarction healing process and left ventricular remodelling. Cardiovasc Res 2009;81:565-573.

47 Sorensen MV, Pedersen S, Mogelvang R, Skov-Jensen J, Flyvbjerg A: Plasma High-Mobility Group Box 1 Levels Predict Mortality After ST-Segment Elevation Myocardial Infarction. JACC Cardiovasc Interv 2011;4:281-286.

-48 Masri FA, Xu W, Comhair SAA, Asosingh K, Koo M, Vasanji A, Drazba J, Anand-Apte B, Erzurum SC: Hyperproliferative apoptosis-resistant endothelial cells in idiopathic pulmonary arterial hypertension. Am J Physiol Lung Cell Mol Physiol2007;293:L548-L554.

-49 Bauer EM, Shapiro R, Zheng H, Ahmad F, Ishizawar D, Comhair SA, Erzurum SC, Billiar TR, Bauer PM: High Mobility Group Box 1 Contributes to the Pathogenesis of Experimental Pulmonary Hypertension via Activation of Toll-like Receptor 4. Mol Med 2012;18:1509-1518.

50 Sadamura-Takenaka Y, Ito T, Noma S, Oyama Y, Yamada S, Kawahara K, Inoue H, Maruyama I: HMGB1 promotes the development of pulmonary arterial hypertension in rats. PLoS One 2014;9:e102482.

-51 Hayakawa K, Mishima K, Irie K, Hazekawa M, Mishima S, Fujioka M, Orito K, Egashira N, Katsurabayashi S, Takasaki K, Iwasaki K, Fujiwara M: Cannabidiol prevents a post-ischemic injury progressively induced by cerebral ischemia via a high-mobility group box1-inhibiting mechanism. Neuropharmacology 2008;55:1280-1286.

-52 Lei C, Lin S, Zhang C, Tao W, Dong W, Hao Z, Liu M, Wu B: Effects of high-mobility group box1 on cerebral angiogenesis and neurogenesis after intracerebral hemorrhage. Neuroscience 2013;229:12-19.

53 Murakami K, Koide M, Dumont TM, Russell SR, Tranmer BI, Wellman GC: Subarachnoid Hemorrhage Induces Gliosis and Increased Expression of the Pro-inflammatory Cytokine High Mobility Group Box 1 Protein. Transl Stroke Res 2011;2:72-79.

-54 Oozawa S: Usefulness of High Mobility Group Box 1 Protein as a Plasma Biomarker in Patient with Peripheral Artery Disease (vol 68, pg 157, 2014). Acta Med Okayama 2014;68:253-253.

55 Biscetti F, Straface G, De Cristofaro R, Lancellotti S, Rizzo P, Arena V, Stigliano E, Pecorini G, Egashira K, De Angelis G, Ghirlanda G, Flex A: High-Mobility Group Box-1 Protein Promotes Angiogenesis After Peripheral Ischemia in Diabetic Mice Through a VEGF-Dependent Mechanism. Diabetes 2010;59:1496-1505.

-56 Bessueille L, Magne D: Inflammation: a culprit for vascular calcification in atherosclerosis and diabetes. Cell Mol Life Sci 2015;72:2475-2489.

-57 Kauppinen A, Paterno JJ, Blasiak J, Salminen A, Kaarniranta K: Inflammation and its role in age-related macular degeneration. Cell Mol Life Sci 2016;73:1765-1786.

-58 Wirrig EE, Yutzey KE: Conserved Transcriptional Regulatory Mechanisms in Aortic Valve Development and Disease. Arterioscler Thromb Vasc Biol 2014;34:737-741.

-59 Yao JY, Guihard PJ, Blazquez-Medela AM, Guo YN, Moon JH, Jumabay M, Bostrom KI, Yao YC: Serine Protease Activation Essential for Endothelial-Mesenchymal Transition in Vascular Calcification. Circ Res 2015;117:758-769.

60 Madhavan MV, Tarigopula M, Mintz GS, Maehara A, Stone GW, Genereux P: Coronary artery calcification: pathogenesis and prognostic implications. J Am Coll Cardiol 2014;63:1703-1714.

61 Qi SC, Cui C, Yan YH, Sun GH, Zhu SR: Effects of high-mobility group box 1 on the proliferation and odontoblastic differentiation of human dental pulp cells. Int Endod J 2013;46:1153-1163.

62 Wolf M, Lossdorfer S, Romer P, Craveiro RB, Deschner J, Jager A: Anabolic properties of high mobility group box protein-1 in human periodontal ligament cells in vitro. Mediators Inflamm 2014;2014:347585.

-63 Lin F, Zhang W, Xue D, Zhu T, Li J, Chen E, Yao X, Pan Z: Signaling pathways involved in the effects of HMGB1 on mesenchymal stem cell migration and osteoblastic differentiation. Int J Mol Med 2016;37:789-797.

64 Meng E, Guo Z, Wang H, Jin J, Wang J, Wang H, Wu C, Wang L: High mobility group box 1 protein inhibits the proliferation of human mesenchymal stem cells and promotes their migration and differentiation along osteoblastic pathway. Stem Cells Dev 2008;17:805-813.

65 Wang B, Li F, Zhang C, Wei G, Liao P, Dong N: High-mobility group box-1 protein induces osteogenic phenotype changes in aortic valve interstitial cells. J Thorac Cardiovasc Surg 2016;151:255-262. 


\section{Cellular Physiology Cell Physiol Biochem 2017;42:427-440 \begin{tabular}{l|l} 
DOI: 10.1159/000477591 & Ond Biochemistry 2017 The Author(s). Published by S. Karger AG, Basel \\
wublished online: May 31, 2017 & and.com/cpb
\end{tabular}}

Chen et al.: Roles of HMGB1 in Cardiovascular Calcification

66 Byon CH, Javed A, Dai Q, Kappes JC, Clemens TL, Darley-Usmar VM, McDonald JM, Chen Y: Oxidative stress induces vascular calcification through modulation of the osteogenic transcription factor Runx2 by AKT signaling. J Biol Chem 2008;283:15319-15327.

67 Zhang J, Zheng B, Zhou PP, Zhang RN, He M, Yang Z, Wen JK: Vascular calcification is coupled with phenotypic conversion of vascular smooth muscle cells through Klf5-mediated transactivation of the Runx2 promoter. Biosci Rep 2014;34:e00148.

68 Sun Y, Byon CH, Yuan K, Chen J, Mao X, Heath JM, Javed A, Zhang K, Anderson PG, Chen Y: Smooth muscle cell-specific runx2 deficiency inhibits vascular calcification. Circ Res 2012;111:543-552.

-69 Slatopolsky E, Caglar S, Gradowska L, Canterbury J, Reiss E, Bricker NS: On the prevention of secondary hyperparathyroidism in experimental chronic renal disease using "proportional reduction" of dietary phosphorus intake. Kidney Int 1972;2:147-151.

70 Estepa JC, Aguilera-Tejero E, Lopez I, Almaden Y, Rodriguez M, Felsenfeld AJ: Effect of phosphate on parathyroid hormone secretion in vivo. J Bone Miner Res 1999;14:1848-1854.

71 Lin ME, Chen T, Leaf EM, Speer MY, Giachelli CM: Runx2 Expression in Smooth Muscle Cells Is Required for Arterial Medial Calcification in Mice. Am J Pathol 2015;185:1958-1969.

72 Byon CH, Chen Y: Molecular Mechanisms of Vascular Calcification in Chronic Kidney Disease: The Link between Bone and the Vasculature. Curr Osteoporos Rep 2015;13:206-215.

73 Vimalraj S, Arumugam B, Miranda PJ, Selvamurugan N: Runx2: Structure, function, and phosphorylation in osteoblast differentiation. Int J Biol Macromol 2015;78:202-208.

74 Xu S, Liu AC, Gotlieb AI: Common pathogenic features of atherosclerosis and calcific aortic stenosis: role of transforming growth factor-beta. Cardiovasc Pathol 2010;19:236-247.

75 Ruiz-Ortega M, Rodriguez-Vita J, Sanchez-Lopez E, Carvajal G, Egido J: TGF-beta signaling in vascular fibrosis. Cardiovasc Res 2007;74:196-206.

-76 Pardali E, Ten Dijke P: TGFbeta signaling and cardiovascular diseases. Int J Biol Sci 2012;8:195-213.

77 Jian B, Narula N, Li QY, Mohler ER, Levy RJ: Progression of aortic valve stenosis: TGF-beta 1 is present in calcified aortic valve cusps and promotes aortic valve interstitial cell calcification via apoptosis. Ann Thorac Surg 2003;75:457-465.

78 Yetkin E, Tchaikovski V, Erdil N, Alan S, Waltenberger J: Increased expression of cystatin C and transforming growth factor beta-1 in calcific aortic valves. Int J Cardiol 2014;176:1252-1254.

79 Zhu D, Mackenzie NC, Shanahan CM, Shroff RC, Farquharson C, MacRae VE: BMP-9 regulates the osteoblastic differentiation and calcification of vascular smooth muscle cells through an ALK1 mediated pathway. J Cell Mol Med 2015;19:165-174.

-80 Krohn JB, Hutcheson JD, Martinez-Martinez E, Irvin WS, Bouten CV, Bertazzo S, Bendeck MP, Aikawa E: Discoidin Domain Receptor-1 Regulates Calcific Extracellular Vesicle Release in Vascular Smooth Muscle Cell Fibrocalcific Response via Transforming Growth Factor-beta Signaling. Arterioscler Thromb Vasc Biol 2016;36:525-533.

81 Cheng M, Liu H, Zhang D, Liu Y, Wang C, Liu F, Chen J: HMGB1 Enhances the AGE-Induced Expression of CTGF and TGF-beta via RAGE-Dependent Signaling in Renal Tubular Epithelial Cells. Am J Nephrol 2015;41:257-266.

-82 He L, Sun F, Wang Y, Zhu J, Fang J, Zhang S, Yu Q, Gong Q Ren B, Xiang X, Chen Z, Ning Q Hu J, Yang P, Wang CY: HMGB1 exacerbates bronchiolitis obliterans syndrome via RAGE/NF-kappaB/HPSE signaling to enhance latent TGF-beta release from ECM. Am J Transl Res 2016;8:1971-1984.

83 Wang Y, Shan J, Yang W, Zheng H, Xue S: High mobility group box 1 (HMGB1) mediates high-glucoseinduced calcification in vascular smooth muscle cells of saphenous veins. Inflammation 2013;36:15921604.

84 Gao J, Zhang K, Chen J, Wang MH, Wang J, Liu P, Huang H: Roles of aldosterone in vascular calcification: An update. Eur J Pharmacol 2016;786:186-193.

-85 Nahar NN, Missana LR, Garimella R, Tague SE, Anderson HC: Matrix vesicles are carriers of bone morphogenetic proteins (BMPs), vascular endothelial growth factor (VEGF), and noncollagenous matrix proteins. J Bone Miner Metab 2008;26:514-519.

-86 Golub EE: Biomineralization and matrix vesicles in biology and pathology. Semin Immunopathol 2011;33:409-417. 


\section{Cellular Physiology Cell Physiol Biochem 2017;42:427-440 \begin{tabular}{l|l} 
DOI: 10.1159/000477591 & and Biochemistry \\
Published online: May 31, 2017 & $\begin{array}{l}\text { 2017 The Author(s). Published by S. Karger AG, Basel } \\
\text { www.karger.com/cpb }\end{array}$
\end{tabular} \\ Chen et al.: Roles of HMGB1 in Cardiovascular Calcification}

87 Candela ME, Geraci F, Turturici G, Taverna S, Albanese I, Sconzo G: Membrane Vesicles Containing Matrix Metalloproteinase-9 and Fibroblast Growth Factor-2 Are Released Into the Extracellular Space From Mouse Mesoangioblast Stem Cells. J Cell Physiol 2010;224:144-151.

88 Shapiro IM, Landis WJ, Risbud MV: Matrix vesicles: Are they anchored exosomes? Bone 2015;79:29-36.

89 Kapustin AN, Chatrou ML, Drozdov I, Zheng Y, Davidson SM, Soong D, Furmanik M, Sanchis P, De Rosales RT, Alvarez-Hernandez D, Shroff R, Yin X, Muller K, Skepper JN, Mayr M, Reutelingsperger CP, Chester A, Bertazzo S, Schurgers LJ, Shanahan CM: Vascular smooth muscle cell calcification is mediated by regulated exosome secretion. Circ Res 2015;116:1312-1323.

90 Johnson RC, Leopold JA, Loscalzo J: Vascular Calcification: Pathobiological Mechanisms and Clinical Implications. Circ Res 2009;105:E8-E8.

-91 Zhu X, Messer JS, Wang Y, Lin F, Cham CM, Chang J, Billiar TR, Lotze MT, Boone DL, Chang EB: Cytosolic HMGB1 controls the cellular autophagy/apoptosis checkpoint during inflammation. J Clin Invest 2015;125:1098-1110.

-92 Ouyang F, Huang H, Zhang M, Chen M, Huang H, Huang F, Zhou S: HMGB1 induces apoptosis and EMT in association with increased autophagy following H/R injury in cardiomyocytes. Int J Mol Med 2016;37:679689.

93 Wang WK, Lu QH, Zhang JN, Wang B, Liu XJ, An FS, Qin WD, Chen XY, Dong WQ, Zhang C, Zhang Y, Zhang MX: HMGB1 mediates hyperglycaemia-induced cardiomyocyte apoptosis via ERK/Ets-1 signalling pathway. J Cell Mol Med 2014;18:2311-2320.

-94 Ishino S, Ogawa M, Mori I, Nishimura S, Ikeda S, Sugita T, Oikawa T, Horiguchi T, Magata Y: 18F-FDG PET and intravascular ultrasonography (IVUS) images compared with histology of atherosclerotic plaques: 18F-FDG accumulates in foamy macrophages. Eur J Nucl Med Mol Imaging 2014;41:624-633.

95 Zhang K, Gao J, Chen J, Liu X, Cai Q, Liu P, Huang H: MICS, an easily ignored contributor to arterial calcification in CKD patients. Am J Physiol Renal Physiol 2016;311:F663-F670.

\$6 New SE, Goettsch C, Aikawa M, Marchini JF, Shibasaki M, Yabusaki K, Libby P, Shanahan CM, Croce K, Aikawa E: Macrophage-derived matrix vesicles: an alternative novel mechanism for microcalcification in atherosclerotic plaques. Circ Res 2013;113:72-77.

-97 Deuell KA, Callegari A, Giachelli CM, Rosenfeld ME, Scatena M: RANKL Enhances Macrophage Paracrine Pro-Calcific Activity in High Phosphate-Treated Smooth Muscle Cells: Dependence on IL-6 and TNF-alpha. J Vasc Res 2012;49:510-521.

-98 Lencel P, Delplace S, Pilet P, Leterme D, Miellot F, Sourice S, Caudrillier A, Hardouin P, Guicheux J, Magne D: Cell-specific effects of TNF-alpha and IL-1beta on alkaline phosphatase: implication for syndesmophyte formation and vascular calcification. Lab Invest 2011;91:1434-1442.

-99 Wang TJ, Larson MG, Levy D, Benjamin EJ, Kupka MJ, Manning WJ, Clouse ME, D'Agostino RB, Wilson PW, O'Donnell CJ: C-reactive protein is associated with subclinical epicardial coronary calcification in men and women: the Framingham Heart Study. Circulation 2002;106:1189-1191.

100 Ibarra Urizar A, Friberg J, Christensen DP, Lund Christensen G, Billestrup N: Inflammatory Cytokines Stimulate Bone Morphogenetic Protein-2 Expression and Release from Pancreatic Beta Cells. J Interferon Cytokine Res 2016;36:20-29.

101 Huang RL, Yuan Y, Tu J, Zou GM, Li Q: Opposing TNF-alpha/IL-1beta- and BMP-2-activated MAPK signaling pathways converge on Runx2 to regulate BMP-2-induced osteoblastic differentiation. Cell Death Dis 2014;5:e1187.

- 102 Ikeda K, Souma Y, Akakabe Y, Kitamura Y, Matsuo K, Shimoda Y, Ueyama T, Matoba S, Yamada H, Okigaki M, Matsubara H: Macrophages play a unique role in the plaque calcification by enhancing the osteogenic signals exerted by vascular smooth muscle cells. Biochem Biophys Res Commun 2012;425:39-44.

103 Passmore M, Nataatmadja M, Fung YL, Pearse B, Gabriel S, Tesar P, Fraser JF: Osteopontin alters endothelial and valvular interstitial cell behaviour in calcific aortic valve stenosis through HMGB1 regulation. Eur J Cardiothorac Surg 2015;48:e20-29.

- 104 Fiuza C, Bustin M, Talwar S, Tropea M, Gerstenberger E, Shelhamer JH, Suffredini AF: Inflammationpromoting activity of HMGB1 on human microvascular endothelial cells. Blood 2003;101:2652-2660.

105 Treutiger CJ, Mullins GE, Johansson AS, Rouhiainen A, Rauvala HM, Erlandsson-Harris H, Andersson U, Yang H, Tracey KJ, Andersson J, Palmblad JE: High mobility group 1 B-box mediates activation of human endothelium. J Intern Med 2003;254:375-385. 


\section{Cellular Physiology Cell Physiol Biochem 2017;42:427-440

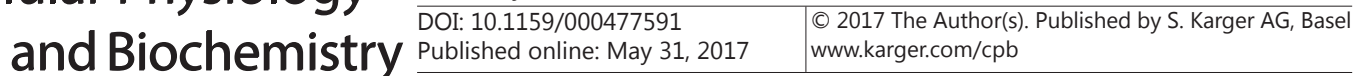 \\ Chen et al.: Roles of HMGB1 in Cardiovascular Calcification}

106 Porto A, Palumbo R, Pieroni M, Aprigliano G, Chiesa R, Sanvito F, Maseri A, Bianchi ME: Smooth muscle cells in human atherosclerotic plaques secrete and proliferate in response to high mobility group box 1 protein. FASEB J 2006;20:2565-2566.

107 Su Z, Yin J, Wang T, Sun Y, Ni P, Ma R, Zhu H, Zheng D, Shen H, Xu W, Xu H: Up-regulated HMGB1 in EAM directly led to collagen deposition by a PKCbeta/Erk1/2-dependent pathway: cardiac fibroblast/ myofibroblast might be another source of HMGB1. J Cell Mol Med 2014;18:1740-1751.

108 Ojo 00, Ryu MH, Jha A, Unruh H, Halayko AJ: High-mobility group box 1 promotes extracellular matrix synthesis and wound repair in human bronchial epithelial cells. Am J Physiol Lung Cell Mol Physiol 2015;309:L1354-1366.

109 Wang HL, Peng LP, Chen WJ, Tang SH, Sun BZ, Wang CL, Huang R, Xu ZJ, Lei WF: HMGB1 enhances smooth muscle cell proliferation and migration in pulmonary artery remodeling. Int J Clin Exp Pathol 2014;7:38363844.

110 Campana L, Santarella F, Esposito A, Maugeri N, Rigamonti E, Monno A, Canu T, Del Maschio A, Bianchi ME, Manfredi AA, Rovere-Querini P: Leukocyte HMGB1 is required for vessel remodeling in regenerating muscles. J Immunol 2014;192:5257-5264.

111 Li H, Horke S, Förstermann U: Vascular oxidative stress, nitric oxide and atherosclerosis. Atherosclerosis 2014;237:208-219.

112 Al-Aly Z: Phosphate, oxidative stress, and nuclear factor-kappaB activation in vascular calcification. Kidney Int 2011;79:1044-1047.

113 Liberman M, Bassi E, Martinatti MK, Lario FC, Wosniak J, Jr., Pomerantzeff PM, Laurindo FR: Oxidant generation predominates around calcifying foci and enhances progression of aortic valve calcification. Arterioscler Thromb Vasc Biol 2008;28:463-470.

114 Sutra T, Morena M, Bargnoux AS, Caporiccio B, Canaud B, Cristol JP: Superoxide production: a procalcifying cell signalling event in osteoblastic differentiation of vascular smooth muscle cells exposed to calcification media. Free Radic Res 2008;42:789-797.

115 Al-Aly Z: Phosphate, oxidative stress, and nuclear factor- $\mathrm{BB}$ activation in vascular calcification. Kidney Int 2011;79:1044-1047.

116 Liberman M, Johnson RC, Handy DE, Loscalzo J, Leopold JA: Bone morphogenetic protein-2 activates NADPH oxidase to increase endoplasmic reticulum stress and human coronary artery smooth muscle cell calcification. Biochem Biophys Res Commun 2011;413:436-441.

117 Tada Y, Yano S, Yamaguchi T, Okazaki K, Ogawa N, Morita M, Sugimoto T: Advanced glycation end productsinduced vascular calcification is mediated by oxidative stress: functional roles of NAD(P)H-oxidase. Horm Metab Res 2013;45:267-272.

118 Wei Q Ren X, Jiang Y, Jin H, Liu N, Li J: Advanced glycation end products accelerate rat vascular calcification through RAGE/oxidative stress. BMC Cardiovasc Disord 2013;13:13.

-119 Al-Aly Z, Shao JS, Lai CF, Huang E, Cai J, Behrmann A, Cheng SL, Towler DA: Aortic Msx2-Wnt calcification cascade is regulated by TNF-alpha-dependent signals in diabetic Ldlr-/- mice. Arterioscler Thromb Vasc Biol 2007;27:2589-2596.

120 Farrar EJ, Huntley GD, Butcher J: Endothelial-derived oxidative stress drives myofibroblastic activation and calcification of the aortic valve. PLoS One 2015;10:e0123257.

121 Tang FT, Chen SR, Wu XQ, Wang TQ Chen JW, Li J, Bao LP, Huang HQ, Liu PQ: Hypercholesterolemia accelerates vascular calcification induced by excessive vitamin D via oxidative stress. Calcif Tissue Int 2006;79:326-339.

122 Yamada S, Taniguchi M, Tokumoto M, Toyonaga J, Fujisaki K, Suehiro T, Noguchi H, Iida M, Tsuruya K, Kitazono T: The antioxidant tempol ameliorates arterial medial calcification in uremic rats: important role of oxidative stress in the pathogenesis of vascular calcification in chronic kidney disease. J Bone Miner Res 2012;27:474-485.

123 Yu Y, Tang D, Kang R: Oxidative stress-mediated HMGB1 biology. Front Physiol 2015;6:93.

124 Yang L, Chai W, Wang Y, Cao L, Xie M, Yang M, Kang R, Yu Y: Reactive oxygen species regulate the differentiation of acute promyelocytic leukemia cells through HMGB1-mediated autophagy. Am J Cancer Res 2015;5:714-725.

125 Mohammad G, Alam K, Nawaz MI, Siddiquei MM, Mousa A, Abu El-Asrar AM: Mutual enhancement between high-mobility group box-1 and NADPH oxidase-derived reactive oxygen species mediates diabetes-induced upregulation of retinal apoptotic markers. J Physiol Biochem 2015;71:359-372. 


\section{Cellular Physiology Cell Physiol Biochem 2017;42:427-440

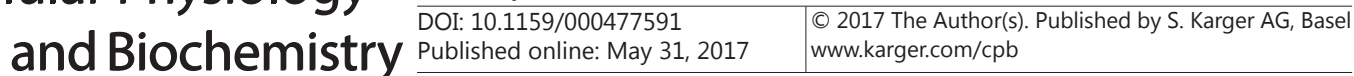 \\ Chen et al.: Roles of HMGB1 in Cardiovascular Calcification}

126 Wu H, Li R, Wei ZH, Zhang XL, Chen JZ, Dai Q, Xie J, Xu B: Diabetes-Induced Oxidative Stress in Endothelial Progenitor Cells May Be Sustained by a Positive Feedback Loop Involving High Mobility Group Box-1. Oxid Med Cell Longev 2016;2016:1943918.

-127 Zhang C, Mo M, Ding W, Liu W, Yan D, Deng J, Luo X, Liu J: High-mobility group box 1 (HMGB1) impaired cardiac excitation-contraction coupling by enhancing the sarcoplasmic reticulum (SR) Ca(2+) leak through TLR4-ROS signaling in cardiomyocytes. J Mol Cell Cardiol 2014;74:260-273.

128 Zhong Z, Sanchez-Lopez E, Karin M: Autophagy, Inflammation, and Immunity: A Troika Governing Cancer and Its Treatment. Cell 2016;166:288-298.

129 Orogo AM, Gustafsson AB: Therapeutic targeting of autophagy: potential and concerns in treating cardiovascular disease. Circ Res 2015;116:489-503.

130 De Meyer GR, Grootaert MO, Michiels CF, Kurdi A, Schrijvers DM, Martinet W: Autophagy in vascular disease. Circ Res 2015;116:468-479.

131 Pei F, Wang HS, Chen Z, Zhang L: Autophagy regulates odontoblast differentiation by suppressing NF- $\mathrm{KB}$ activation in an inflammatory environment. Cell Death Dis 2016;7:e2122.

132 Kaluderovic MR, Mojic M, Schreckenbach JP, Maksimovic-Ivanic D, Graf HL, Mijatovic S: A Key Role of Autophagy in Osteoblast Differentiation on Titanium-Based Dental Implants. Cells Tissues Organs 2014;200:265-277.

133 Gomez-Puerto MC, Verhagen LP, Braat AK, Lam EW, Coffer PJ, Lorenowicz MJ: Activation of autophagy by FOXO3 regulates redox homeostasis during osteogenic differentiation. Autophagy 2016;12:1804-1816.

134 Pantovic A, Krstic A, Janjetovic K, Kocic J, Harhaji-Trajkovic L, Bugarski D, Trajkovic V: Coordinated timedependent modulation of AMPK/Akt/mTOR signaling and autophagy controls osteogenic differentiation of human mesenchymal stem cells. Bone 2013;52:524-531.

135 Salabei JK, Cummins TD, Singh M, Jones SP, Bhatnagar A, Hill BG: PDGF-mediated autophagy regulates vascular smooth muscle cell phenotype and resistance to oxidative stress. Biochem J 2013;451:375-388.

136 Dai XY, Zhao MM, Cai Y, Guan QC, Zhao Y, Guan Y, Kong W, Zhu WG, Xu MJ, Wang X: Phosphate-induced autophagy counteracts vascular calcification by reducing matrix vesicle release. Kidney Int 2013;83:10421051.

137 Liu D, Cui W, Liu B, Hu H, Liu J, Xie R, Yang X, Gu G, Zhang J, Zheng H: Atorvastatin protects vascular smooth muscle cells from TGF-beta1-stimulated calcification by inducing autophagy via suppression of the betacatenin pathway. Cell Physiol Biochem 2014;33:129-141.

138 Yang J, Chen L, Ding J, Fan Z, Li S, Wu H, Zhang J, Yang C, Wang H, Zeng P, Yang J: MicroRNA-24 inhibits high glucose-induced vascular smooth muscle cell proliferation and migration by targeting HMGB1. Gene 2016;586:268-273.

139 Yang PS, Kim DH, Lee YJ, Lee SE, Kang WJ, Chang HJ, Shin JS: Glycyrrhizin, inhibitor of high mobility group box-1, attenuates monocrotaline-induced pulmonary hypertension and vascular remodeling in rats. Respir Res 2014;15:148.

140 Liu M, Yu Y, Jiang H, Zhang L, Zhang PP, Yu P, Jia JG, Chen RZ, Zou YZ, Ge JB: Simvastatin suppresses vascular inflammation and atherosclerosis in ApoE(-/-) mice by downregulating the HMGB1-RAGE axis. Acta Pharmacol Sin 2013;34:830-836. 